\title{
ANALISIS PIUTANG USAHA PADA PERUSAHAAN DAERAH AIR MINUM (PDAM) DI AIRMADIDI KABUPATEN MINAHASA UTARA
}

\author{
Erlita Mentari Lahengking ${ }^{1}$, Inggriani Elim² ${ }^{2}$, Rudy Pusung ${ }^{3}$ \\ 1,2,3 Jurusan Akuntansi, Fakultas Ekonomi dan Bisnis, Universitas Sam Ratulangi, Jl. Kampus Unsrat, Kota \\ Manado, 95115, Indonesia \\ E-mail: mentaryerlita@gmail.com
}

\begin{abstract}
Accounts receivable of a company generally represent the bulk of current assets and the largest part of the total assets of the company. Therefore, good accounting and accounting management of these accounts receivable is very important to be applied. This study aims to determine the management and recording of accounting receivables and accounts receivable analysis applied to PDAM Kabupaten Minahasa Utara. The object of this research is PDAM Kabupaten Minahasa Utara. The method used in this study is descriptive method is a method used to draw or analyze, comparing a research result but not used to make wider conclusions. Sources of data used are secondary data that is financial report data PDAM Kabupaten Minahasa Utara in the period 2013 until the period 2015 obtained from PDAM Kabupaten Minahasa Utara. The results showed that PDAM Kabupaten Minahasa Utara has applied SAK ETAP on accounting management and accounting records but there are still some provisions that have not been implemented PDAM Kabupaten Minahasa Utara in accordance with SAK ETAP so there are many bad debts. The result of analysis of Receivable Turn Over (RTO) and Average Collection Period $(A C P)$ ratio shows that receivable turnover and receivable collection do not match with the target company.

Keywords : Accounts Receivable, Accounts Receivable Turnover, Receivables Collection, SAK-ETAP
\end{abstract}

\section{PENDAHULUAN}

Piutang usaha suatu perusahaan pada umumnya merupakan bagian terbesar dari aktiva lancar serta bagian terbesar dari total aktiva perusahaan. Piutang meliputi semua tagihan dalam bentuk utang kepada perorangan badan usaha atau pihak lainnya. Piutang adalah pos penting dalam perusahaan karena merupakan aktiva lancar yang likuid dan selalu dalam keadaan berputar.

Penagihan piutang sering tidak tepat pada waktu yang sudah ditetapkan sebelumnya, sementara perusahaan memerlukan aliran kas yang cukup untuk diputar dalam membiayai aktifitas operasional perusahaan sehari-hari dan memenuhi kewajiban lancar perusahaan tepat pada waktunya.Seberapa cepat piutang dikonversikan menjadi kas merupakan kebijakan perusahaan dengan menghitung perputaran piutang (Banteng, 2013).

Perputaran piutang menunjukan berapa kali perusahaan menagih piutangnya dalam satu periode atau kemampuan dana yang tertanam dalam suatu peiode tertentu (Kasmir, 2012:189). Rasio ini menggambarkan seberapa efisiensinnya suatu perusahaan dalam mengelola piutangnya. Tingkat perputaran piutang diukur dengan membandingkan antara penjualan kredit dengan rata-rata piutangnya.

Periode pengumpulan piutang, menurut Sutrino dalam Nurjannah (2012:52) rasio ini disebut juga dengan rata-rata periode pengumpulan piutang. Rasio ini mengukur efisiensi pengelolaan piutang perusahaan, rata-rata jangka waktu penagihan adalah rata-rata jangka 
waktu lamanya perusahaan harus menunggu pembayaran setelah melakukan penjualan. Semakin pendek periodenya semakin baik.

Akuntansi yang diterapkan di PDAM yang didasarkan pada Pedoman Sistem Akuntansi PDAM yang dikeluarkan oleh kantor menteri Negara otonomi daerah RI dengan surat Keputusan Menteri Negara Otonomi Daerah RI No. 8 tahun 2000, tentang penilaian piutang pada PDAM khusus untuk piutang usaha, ketentuan ini menghendaki agar piutangpiutang yang mempunyai kemungkinan tak tertagih hendaknya dibuatkan penyisihan dalam jumlah yang layak. Untuk menentukan besarnya penyisihan pada tiap akhir tahun. Pengelompokkan piutang menurut umurnya (aging schedule) harus dibuat terlebih dahulu sebagai dasar perhitungan.

Besarnya penyisihan piutang yang belum dibayarkan pada tiap akhir tahun ditentukan yaitu di atas 3 bulan sampai dengan 6 bulan penyisihan piutang sebesar 30\%, di atas 6 bulan sampai dengan 12 bulan sebesar 50\%, di atas 1 tahun sampai dengan 2 tahun sebesar $75 \%$, dan di atas 2 tahun sebesar $100 \%$. Namun penyisihan piutang tersebut dikecualikan bagi tagihan kepada seluruh instansi pemerintah, dalam hal kejadian-kejadian khusus misalnya adanya pembongkaran daerah pemukiman tertentu untuk tujuan pembangunan, tagihantagihan tersebut sudah dapat diusulkan penghapusannya walaupun belum memenuhi ketentuan tersebut.Jika terdapat pembayaran atas piutang-piutang yang telah dihapus, pembayarannya tersebut dibukukan sebagai pendapatan lain-lain tahun berjalan.

Piutang yang telah berumur diatas 1 sampai dengan 2 tahun diklasifikasikan sebagai piutang ragu-ragu, sedangkan yang berumur diatas 2 tahun diklasifikasikan sebagai piutang tak tertagih dan sudah dapat diusulkan kepada Badan Pengawas untuk dihapus serta dikeluarkan dari pembukuan, tetapi dicatat sebagai extra comptabel dan tetap diusahakan penagihannya (SAK-ETAP 2015:42).

PDAM Kabupaten Minahasa Utara merupakan perusahaan yang bergerak dalam bidang penyediaan air bersih untuk kebutuhan seluruh masyarakat di Kabupaten Minahasa Utara. Dalam kegiatan usahanya, Perusahaan Daerah Air Minum (PDAM) Kabupaten Minahasa Utara melakukan penjualan air secara kredit karena penjualan kredit merupakan salah satu cara untuk meningkatkan volume penjualan.

Penjualan kredit ini diberikan kepada langganan untuk memanfaatkan pemakaian air bulan ini akan dibayar pada bulan berikutnya artinya langganan diberi kelonggaran atau kemudahan dalam pemakaian air. Dengan adanya kebijakan penjualan kredit ini, langganan menjadi kurang efisien dalam pembayaran air. Akibat penjualan air secara kredit menyebabkan suatu tagihan berupa piutang.

Petunjuk teknis penerapan SAK-ETAP PDAM tersebut telah dijelaskan bahwa PDAM harus menyisihkan piutang usaha setiap tahunnya sebagai bentuk penerapan prinsip konservatisme laporan keuangan. Di dalam petunjuk teknis penerapan SAK-ETAP PDAM tersebut juga telah dilampirkan ketentuan mengenai cara menghitung berapa banyak piutang yang harus disisikan sebagai piutang usaha. Akan tetapi, PDAM Kabupaten Minahasa Utara hanya menerapkan penyisihan piutang dengan menggunakan angka presentasi yang dibuat oleh bagian piutang perusahaan dengan tidak menerapakan sistem penyisihan piutang usaha seperti yang diinstruksikan dalam petunjuk teknis penerapan SAK-ETAP PDAM.

Uraian latar belakang diatas, maka peneliti tertarik ingin mengetahui bagaimana pengelolaan dan pencatatan akuntansi piutang serta analisis piutang usaha yang diterapkan oleh Perusahaan Daerah Air Minum (PDAM) Kabupaten Minahasa Utara dengan mengangkat judul "Analisis Piutang Usaha Pada Perusahaan Daerah Air Minum (PDAM) di Airmadidi Kabupaten Minahasa Utara”. 


\section{TINJAUAN PUSTAKA}

\subsection{Konsep Akuntansi}

Akuntansi adalah suatu disiplin ilmu yang terus berkembang sejalan dengan makin meningkatnya kebutuhan informasi keuangan. Perkembangan tersebut telah menempatkan akuntansi menjadi bagian yang tidak terpisahkan dari roda pemerintahan dan dunia usaha (Wowor, 2017).

Akuntansi menurut Hery (2013:8), meliputi seluruh proses pelaporan, mulai dari pengidentifikasian transaksi bisnis, pencatatan, perkomunikasian (dalam bentuk laporan), sampai pada tahapan analisis dan interpretasi,Tujuan akuntansi secara keseluruhan adalah memberikan informasi yang dapat digunakan dalam pengambilan keputusan (Tinungki, 2014). Sadeli (2015 : 2) menyatakan bahwa akuntansi digunakan untu mencatat, meringkas, melaporkan, menginterpretasikan data dasar ekonomi untuk kepentingan perorangan, pengusaha, pemerintah, dan anggota masyarakat lainnya.

\subsection{Konsep Piutang}

Piutang menurut Standar Akuntansi Keuangan (SAK) pada PDAM "Piutang adalah hak tagih PDAM kepada pihak lain sebagai akibat penyerahan barang atau jasa di masa lalu. Piutang terdiri dari piutang usaha dan piutang non usaha. Piutang usaha adalah piutang yang timbul dari transaksi penjualan air dan non air, sedangkan piutang non usaha adalah piutang yang timbul dari transaksi lainnya".

Piutang menurut Kieso (2013:368) menyataan bahwa yang dimaksud dengan piutang adalah sebagai berikut "piutang didefinisikan sebagai jumlah yang dapat ditagih dalam bentuk tunai dari seseorang atau perusahaan lain."Warren (2013 : 442) menyatakan bahwa "piutang meliputi semua klaim dalam bentuk uang terhadap pihak lainnya termasuk individu, perusahaan atau organisasi lainnya."Sedangkan menurut Syakur (2015:140) piutang menunjukan adanya klaim perusahaan kepada pihak (perusahaan) lain akibat kejadian di waktu sebelumnya dalam bentuk uang, barang, jasa atau dalam bentuk aktiva non kas lainnya yang harus dilakukan penagih (collect) pada tanggal jatuh temponya.

\subsubsection{Klasifikasi Piutang}

Klasifikasi Piutang menurut Hery (2015: 203) dalam praktek, piutang pada umumnya dikalsifikasikan menjadi :

1. Piutang Usaha (Accounts Receivable)

Jumlah yang akan ditagih dari pelanggan sebagai akibat penjualan barang atau jasa secara kredit. Piutang usaha memiliki saldo normal untuk aset.Piutang usaha biasanya diperkirakan akan dapat ditagih dalam jangka waktu yang relative pendek, biasanya dalam 30 hingga 60 hari. Setelah ditagih, secara pembukuan, piutang usaha akan berkurang disebelah kredit. Piutang usaha diklasifikasikan dalam neraca sebagai aset lancar (current asset).

2. Piutang Wesel (Notes Receivable)

3. Piutang Lain-lain (Other Receivables)

\subsubsection{Pengakuan Piutang}

Akun piutang usaha pertama kali akan timbul oleh karena penjualan barang secara kredit, yang kemudian dapat diikuti dengan transaksi retur penjualan, penyesuaian atau pengurangan harga jual, dan pada akhirnya penagihan (baik tanpa maupun disertai dengan pemberian potongan penjualan).

Ayat jurnal yang perlu dibuat oleh penjual pada saat melakukan transaksi penjualan barang dagangan secara kredit, yaitu (Hery, 2015;208) : 


\section{Piutang Usaha $\quad$ XXX \\ Penjualan XXX}

Ayat jurnal yang dibuat oleh penjual pada saat menerima kembali barang dagangan yang telah dijualnya secara kredit atau pada saat memberikan penyesuaian/pengurangan harga jual kepada langgannya, yaitu (Hery, 2015;208) :

Retur penjualan \& penyesuaian harga jual XXX
Piutang Usaha
XXX

Ayat jurnal yang akan dibuat oleh penjual pada saat menerima pembayaran utang dari pelanggan yang memanfaatkan potongan tunai (selama periode potongan) adalah sebagai berikut (Hery, 2015;209) :

$\begin{array}{ll}\text { Kas } & \text { XXX } \\ \text { Potongan Penjualan } & \text { XXX }\end{array}$

Piutang Usaha

XXX

Perusahaan jasa, akun piutang usaha akan timbul apabila perusahaan belum menerima pembayaran atas jasa yang secara substansial telah selesai diberikan kepada pelanggan. Dalam Hal ini, ayat jurnal yang perlu dibuat oleh pemberi jasa dalam bukunya adalah sebagai berikut (Hery, 2015;209) :
Piutang Usaha
XXX
Pendapatan Jasa
$\mathrm{XXX}$

\subsubsection{Penyisihan Kerugian Piutang}

Penyisihan kerugian piutang menurut buku pedoman SAK ETAP pada PDAM (2015), adalah sebagai berikut :

1) Piutang Usaha

Pada setiap tanggal pelaporan, penyisihan kerugian piutang usaha dihitung berdasarkan rata-rata piutang usaha tak tertagih pada masing-masing kelompok secara kolektif/kelompok pelanggan (pelanggan rumah tangga, niaga, sosial, industri, instansi pemerintah, dan lain-lain). Penyisihan kerugian piutang usaha dibentuk untuk menutup kemungkinan kerugian yang timbul.

2) Piutang Non Usaha

Pada setiap tanggal pelaporan, penyisihan kerugian piutang non usaha dihitung berdasarkan kemampuan membayar debitur secara individual, yang dibentuk untuk menutup kemungkinan kerugian yang timbul.

\subsubsection{Piutang Usaha Tidak Dapat Ditagih}

Menurut Hery $(2015 ; 210)$ ada 2 (dua) metode yang digunakan untuk menilai, mencatat, atau menghapus langsung piutang usaha yang tidak dapat ditagih, yaitu :

1. Metode hapus langsung (direct write-off method)

2. Metode pencadangan (allowance method)

\section{a. Metode Hapus Langsung.}

Metode hapus langsung (direct write-off method) adalah metode penghapusan piutang yang langsung dihapus dari saldo piutang perusahaan jika piutang tersebut telah benar - benar tidak dapat ditagih setelah melakukan upaya-upaya penagihan (Banteng, 2013).

Jadi, dalam hal ini ayat jurnal yang perlu dibuat oleh perusahaan untuk mencatat besarnya actual loss adalah sebagai berikut (Hery, 2015;211) :

Beban piutang yang tidak dapat ditagih

XXX

$$
\text { Piutang usaha - Tn.X }
$$

XXX

Metode penghapusan langsung sangatlah sederhana, akan tetapi metode ini tidak sesuai dengan konsep penandingan (matching concept). Metode hapus langsug diterapkan ketika 
besarnya kredit atau piutang usaha adalah sanggat kecil, sehingga berdasarkan prinsip materialitas maka metode yang simple ini diperbolehkan dipakai meskipun untuk tujuan pembukuan. Namun secara keseluruhan, menurut prinsip-prinsip akuntansi yang berlaku umum, metode hapus langsung tidaklah diperkenankan untuk tujuan pembukuan (book purposes).

\section{b. Metode Pencadangan}

Metode pencadangan adalah metode yang digunakan oleh suatu perusahaan untuk menyisikan piutangnya sebagai cadangan piutang ragu-ragu atau cadangan piutang tak tertagih (Banteng, 2013). Akun cadangan ini akan mengurangi jumlah bruto piutang ke nilai bersihnya yang dapat direalisasi (Hery, 2015).Untuk tujuan pembukuan, metode pencadangan diharuskan menurut prinsip-prinsip akuntansi yang selalu berlaku umum, karena memenuhi syarat atau sesuai dengan :

1. Prinsip Penandingan (the matching principle) - dimana besarnya estimasi atas beban piutang tak tertagih dicatat dalam periode yang sama sebagaimana pendapatan penjualan dicatat.

2. Prinsip Konservatisme (the conservatism principle) - dimana piutang usaha dilaporkan dalam neraca sebesar jumlah yang lebih realistis (dan lebih rendah) sehingga mencerminkan dengan baik jumlah piutang sesungguhnya dapat ditagih.

Ayat jurnal yang perlu dibuat oleh perusahaan untuk mencatat besarnya estimasi atas beban piutang tak tertagih adalah sebagai berikut (Hery, 2015;214) :

Beban piutang yang tidak dapat ditagih

$\mathrm{XXX}$

Cadangan piutang yang tidak dapat ditagih

XXX

Perusahaan mendapati bahwa ada pelanggan tertentunya tidak bisa membayar, maka ayat jurnal yang perlu dibuat oleh perusahaan untuk mencatat penghapusan piutang atas pelanggan aktual tersebut adalah sebagai berikut (Hery, 2015;214) :

Cadangan piutang yang tidak dapat ditagih

Piutang usaha - Tn. Y

YYY

YYY

\subsubsection{Pengungkapan dan Penyajian Piutang}

Pengungkapan dan penyajian piutang menurut Kieso (2013;25), Setiap jenis utama dari piutang harus disebutkan dalam neraca atau catatan atas laporan keuangan. Piutang jangka pendek akan dilaporkan sebagai bagian aset lancar dineraca, dibawah investasi jangka pendek. Investasi jangka pendek disajikan sebelum piutang, Karena investasi jangka pendek lebih likuid (lebih cepat dikonversikan menjadi bentuk kas) danjumlah piutang kotor dan penyisihan piutang tak tertagih, keduanya harus dilaporkan secara bersama-sama.

\subsubsection{Penilaian Piutang SAK-ETAP}

Penilaian piutang menurut (SAK ETAP 2015:42), Penilaian harus disajikan dalam laporan keuangan dengan nilai tunai yang dapat direalisasikan. Khusus untuk piutang usaha ketentuan ini menghendaki agar piutang-piutang yang mempunyai kemungkinan tak tertagih hendaknya dibuatkan penyisihan dalam jumlah layak. Untuk menentukan besarnya penyisihan pada tiap akhir tahun pengelompokan piutang menurut umurnya (aging schedule) harus dibuat terlebih dahulu sebagai dasar perhitungan. Besarnya penyisihan piutang pada tiap akhir tahun ditentukan sebagai berikut :

Di atas 3 bulan s.d 6 bulan : $: 30 \%$

Di atas 6 bulan s.d 12 bulan : $50 \%$

Di atas 1 tahun s.d 2 tahun $\quad: 75 \%$, diajukan ke Badan Pengawas untuk dihapus

Di atas 2 tahun $\quad: 100 \%$, dan dikeluarkan dari Pembukuan, tetapi masih

tercatat secara extra comptabel. 
Penyisihan piutang tersebut diatas dikecualikan bagi tagihan kepada seluruh instansi Pemerintah. Dalam hal kejadian - kejadian khusus, misalnya adanya pembongkaran daerah pemukiman tertentu untuk tujuan pembagunan, tagihan-tagihan tersebut sudah dapat diusulkan penghapusannya walaupun belum memenuhi ketentuan diatas. Jika terdapat pembayaran atas piutang-piutang yang telah dihapus, pembayaran tersebut dibukukan sebagai Pendapatan lain-lain tahun berjalan.

Piutang yang telah berumur diatas 1 (satu) tahun s.d 2 (dua) tahun diklasifikasikan sebagai Piutang ragu-ragu, sedangkan yang berumur diatas 2 (dua) tahun diklasifikasikan sebagai piutang tak tertagih dan sudaha dapat diusulkan kepada Badan Pengawas untuk dihapuskan serta dikeluarkan dari pembukuan, tetapi dicatat secara extra comptabel dan tetap diusahakan penagihannya.

\subsection{Rasio Yang Berhubungan dengan Piutang Usaha}

\subsubsection{Perputaran Piutang/Receviable Turn Over (RTO)}

Perputaran tingkat piutang rendah berarti piutang membutuhkan waktu yang cukup lama untuk ditagih menjadi uang tunai atau menunjukan modal kerja yang ditanamkan dalam piutang besar (Kasmir, 2012:176). Perputaran juga disebut dengan RTO. Perhitungannya sebagai berikut :

$$
\text { RTO }=\frac{\text { Penjualan Kredit }}{\text { Piutang Rata-rata }}=\ldots \ldots \ldots . . \text { kali }
$$

\subsubsection{Periode Pengumpulan Piutang/Average Collection Period (ACP)}

Perputaran piutang waktunya dinyatakan dalam hari, hal ini disebabkan syarat pembayaran yang ditetapkan didalam transaksi penjualan dinyatakan dalam satuan hari sebagai satuan waktu. Perhitungannya sebagai berikut :

$$
\mathrm{ACP}=\frac{360}{\mathrm{RTO}}=\ldots \ldots \ldots \text {.hari }
$$

\subsubsection{Rasio Tunggakan}

Rasio tunggakan menurut Keown dalam Nurjannah (2012,54), rasio tunggakan ini dapat digunakan untuk mengetahui berapa besar jumlah piutang yang telah jatu tempo dari sejumlah penjualan kredit yang belum tertagih. Perhitungannya sebagai berikut :

$$
\text { Rasio Tunggakan }=\frac{\text { Saldo Piutang tak Tertagih }}{\text { Penjualan Kredit }} \times 100 \%
$$

\subsubsection{Rasio Penagihan}

Melengkapi dan mendukung alat analisis sebelumnya maka rasio penagihan ini digunakan untuk mengetahui sejauhmana aktivitas penagihan yang dilakukan oleh perusahaan. Angka rasio ini menunjukkan kemampuan perusahaan dalam upaya penagihan dan pengembalian piutang (Nurjannah, 2012).Perhitungannya sebagai berikut :

$$
\text { Rasio Penagihan }=\frac{\text { Jumlah Piutang Tertagih }}{\text { Total Piutang/Periode }} \times 100 \%
$$




\section{METODE PENELITIAN}

\subsection{Jenis Penelitian}

Metode penelitian harus menggunakan jenis dan sumber data yang akurat dan tepat sehingga memudahkan penelitian.

\subsubsection{Jenis Data}

Jenis data menurut (Sugiyono, 2013:13), data merupakan sekumpulan informasi yang diperlukan untuk mengambil keputusan. Menurut jenisnya data dibedakan menjadi dua data, yaitu sebagai berikut.

1. Data Kuantitatif

Data Kuantitatif adalah penelitian yang banyak menuntut penggunaan angka, mulai dari pengumpulan data, penafsiran terhadap data tersebut, serta penampilan dari hasilnya.

2. Data Kualitatif

Data kualitatif adalah data yang disajikan lebih bersifat deskriptif atau data yang terkumpul berbentuk uraian tentang keadaan dan ruang lingkup perusahaan, sehingga tidak menekankan pada angka.

Dalam penelitian ini, peneliti menggunakan data kualitatif sebagai dasar untuk menganalisis pengelolaan dan pencatatan akuntansi piutang serta menganalisis piutang yang diterapkan pada Perusahaan Daerah Air Minum (PDAM) Kabupaten Minahasa Utara.

\subsubsection{Sumber Data}

1. Sumber Primer

Sumber primer adalah sumber data yang secara langsung memberikan data kepada pengumpul data (Sugiyono, 2012:225). Sumber primer ini berupa catatan hasil wawancara yang diperoleh melalui wawancara yang penulis lakukan. Selain itu, penulis juga melakukan observasi lapangan dan mengumpulkan data dalam bentuk catatan tentang situasi dan kejadian di perpustakaan.

2. Sumber Sekunder

Sumber data sekunder merupakan sumber data yang tidak memberikan informasi secara langsung kepada pengumpul data. Sumber data sekunder ini dapat berupa hasil pengolahan lebih lanjut dari data primer yang disajikan dalam bentuk lain atau dari orang lain (Sugiyono, 2012:225). Data ini digunakan untuk mendukung infomasi dari data primer yang diperoleh baik dari wawancara, maupun dari observasi langsung ke lapangan. Penulis juga menggunakan data sekunder hasil dari studi pustaka, dan dalam studi pustaka, penulis membaca literatur-literatur yang dapat menunjang penelitian, yaitu literatur-literatur yang berhubungan dengan penelitian ini.

Jadi, sumber data yang digunakan dalam penelitian ini adalah data primer dan sekunder. Data primer berupa data hasil wawancara yang dilakukan kepada karyawan PDAM Kabupaten Minahasa Utara secara langsung. Sedangkan data sekunder berupa informasi-informasi tentang perusahaan dalam bentuk arsip maupun buku dan melalui studi dokumentasi dengan mempelajari berbagai tulisan dalam buku, internet, jurnal, skripsi yang berhubungan dengan penelitian.

\subsection{Tempat Penelitian dan Waktu Penelitian}

Objek penelitian ini adalah Perusahaan Daerah Air Minum (PDAM) Kabupaten Minahasa Utara, tentang Analisis Piutang Usaha Pada Perusahaan Daerah Air Minum (PDAM) di Airmadidi Kabupaten Minahasa Utara. Alamat penelitian adalah Jl. Worang By Pass, Kel. Airmadidi Atas Kec. Airmadidi.Waktu penelitian pada PDAM Kabupaten Minahasa Utara adalah 3 (tiga) bulan. 


\subsection{Prosedur Penelitian}

Prosedur penelitian ini meliputi langkah-langkah sebagai berikut:

Alur Prosedur Penelitian

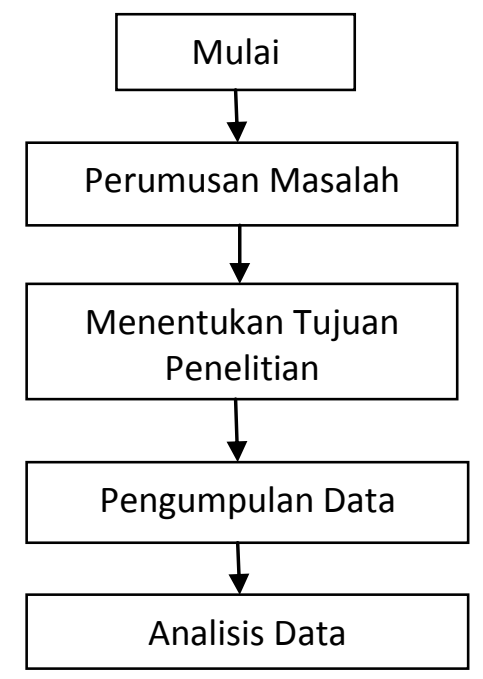

\subsection{Metode Pengumpulan Data}

Teknik pengumpulan data adalah metode atau cara yang dilakukan oleh peneliti untuk memperoleh data atau keterangan yang benar dan dapat dipertanggung jawabkan untuk mendukung penelitiannya. Teknik yang digunakan dalam penelitian ini meliputi:

1. Penelitian Lapangan (field research), teknik ini dilakukan dengan melaksanakan penelitian lapangan yang dilakukan di Perusahaan Daerah Air Minum (PDAM) Kabupaten Minahasa Utara yang merupakan objek penelitian, untuk mendapatkan data yang diperlukan serta peninjauan langsung ke lokasi penelitian. Dalam Penelitian lapangan ini, penelitian yang dapat dilakukan dengan meliputi:

a) Teknik Wawancara (Interview), yaitu mengumpulkan, mencari data dan informasi pada pimpinan perusahaan dan staf di bidang finance \& Accounting dengan masalah penelitian kemudian mengajukan pertanyaan mengenai gambaran umum perusahaan, pengelolaan dan pencatatan akuntansi piutang serta menganalisis piutang yang diterapkan pada Perusahaan Daerah Air Minum (PDAM) Kabupaten Minahasa Utara.

b) Teknik dokumentasi,yaitu dengan mengumpulan dokumen-dokumen yang berhubungan dengan gambaran umum perusahaanpengelolaan dan pencatatan akuntansi piutang serta menganalisis piutang yang diterapkan pada Perusahaan Daerah Air Minum (PDAM) Kabupaten Minahasa Utara.

\subsection{Metode Analisis Data}

Metode penelitian yang digunakan dalam penelitian ini adalah metode deskriptif. Metode deskriptif adalah metode yang digunakan untuk menggambar atau menganalisis, membandingkan suatu hasil penelitian tetapi tidak digunakan untuk membuat kesimpulan yang lebih luas (Sugiyono, 2012;21). Dalam penelitian ini metode analisis deskriptif yang akan diterapkan untuk menganalisis piutang usaha pada Perusahaan Daerah Air Minum (PDAM) Kabupaten Minahasa Utara. Metode analisis ini dapat dilihat sebagai berikut :

1. Mengumpulkan data-data yang berkaitan dengan terjadinya piutang pada Perusahaan Daerah Air Minum (PDAM) Kabupaten Minahasa Utara. 
2. Menganalisis pencatatan piutang air SAK-ETAP dengan PDAM Minut, dan menganalisis piutang perputaran piutang dan pengumpulan piutang dalam periode berdasarkan RTO dan ACP.

3. Mempelajari dan mengevaluasi pencatatan piutang air dan analisis rasio yang digunakan.

4. Berdasarkan hasil analisis diambil kesimpulan dan diberikan saran-saran yang diperlukan.

Tabel 1

Hasil Penelitian dan Pembahasan, Prosedur Akuntansi yang dijalankan PDAM Kabupaten Minahasa Utara dengan Pencatatan Penjualan Air, Piutang Air SAK ETAP

\begin{tabular}{|c|c|c|}
\hline No & $\begin{array}{c}\text { Hasil Penelitian } \\
\text { Pencatatan Transaksi Penjualan Air, Piutang } \\
\text { Rekening Air SAK - ETAP }\end{array}$ & $\begin{array}{c}\text { Pembahasan } \\
\text { Perusahaan Daerah Air Minum } \\
\text { (PDAM) Kabupaten Minahasa Utara }\end{array}$ \\
\hline \multirow[t]{2}{*}{1.} & $\begin{array}{l}\text { Penerimaan Piutang Rekening Air } \\
\text { Pengakuan atas Penerimaan Rekening Air } \\
\text { (Piutang Air), yaitu pada saat pelanggan } \\
\text { melakukan pembayaran melalui Laporan } \\
\text { Penerimaan Penagihan Air (LPP-A). }\end{array}$ & Penerimaan Piutang Rekening Air \\
\hline & $\begin{array}{l}\text { Cara pencatatan: } \\
\begin{array}{l}\text { Dokumen } \\
\text { Air (LPP-A) }\end{array} \\
\begin{array}{l}\text { Buku Jurnal Laporan Penerimaan Penagihan } \\
\text { (JPKB) }\end{array} \\
\begin{array}{l}\text { Debet : Jarnal Penerimaan Kas/Bank } \\
\text { Kredit : Piutang Rekening Air }\end{array}\end{array}$ & $\begin{array}{l}\text { Cara pencatatan: } \\
\text { Dokumen : Laporan Penerimaan } \\
\text { Penagihan Air (LPP-A) } \\
\text { Buku Jurnal : Jurnal Penerimaan } \\
\text { Kas/Bank (JPKB) } \\
\text { Debet : Kas/Bank } \\
\quad \text { Kredit : Piutang Rekening Air }\end{array}$ \\
\hline \multirow[t]{2}{*}{2.} & $\begin{array}{l}\text { Pembuatan Rekening Air } \\
\text { Pengakuan piutang rekening air adalah pada } \\
\text { saat diterbitkan Rekening Air melalui Daftar } \\
\text { Rekening Air yang Ditagihkan (DRD-A). }\end{array}$ & Pembuatan Rekening Air \\
\hline & $\begin{array}{l}\text { Cara pencatatan : } \\
\text { Dokumen } \quad \text { : Daftar Rekening Air yang } \\
\text { Ditagihkan (DRD-A) } \\
\text { Buku Jurnal : Jurnal Rekening Air dan Non Air } \\
\text { (JR) } \\
\text { Debet : Piutang Rekening Air } \\
\text { Kredit : Pendapatan Penjualan Air } \\
\text { Buku Pembantu : } \\
\text { Debit : Harga air } \\
\text { Debit : Pendapatan Jasa Administrasi } \\
\quad \text { Kredit : Cadangan Dana meter }\end{array}$ & $\begin{array}{l}\text { Cara pencatatan : } \\
\text { Dokumen : Daftar Rekening Air } \\
\text { yang Ditagihkan (DRD-A) } \\
\text { Buku Jurnal : Jurnal Rekening Air } \\
\text { dan Non Air (JR) } \\
\text { Debet : Piutang Rekening Air } \\
\text { Kredit : Pendapatan Penjualan Air } \\
\text { Buku Pembantu : } \\
\text { Debit : Harga air } \\
\text { Debit : Pendapatan Jasa Administrasi } \\
\quad \text { Kredit : Cadangan Dana meter }\end{array}$ \\
\hline \multirow[t]{2}{*}{3.} & Penyisihan Kerugian Piutang Air : & Penyisihan Kerugian Piutang Air : \\
\hline & $\begin{array}{l}\text { Pembentukan Penyisihan Piutang Rekening Air } \\
\text { dilakukan pada saat akhir tahun setelah perusahaan } \\
\text { melakukan opname Rekening Air dan melakukan } \\
\text { penghitungan penyisihan kerugian piutang secara } \\
\text { time series (rata-rata piutang tidak tertagih dalam } \\
\text { satu tahun buku selama } 3 \text { periode) dan laporan dari } \\
\text { bagian Hubungan Pelanggan tentang pemutusan } \\
\text { Sambungan Langganan (SL). }\end{array}$ & $\begin{array}{l}\text { PDAM membuat penyisihan tidak } \\
\text { berdasarkan laporan piutang yang valid, } \\
\text { laporan umur piutang, dan laporan dari } \\
\text { bagian hubungan langganan tentang } \\
\text { pemutusan sambungan langganan. } \\
\text { PDAM menghitung penyisihan piutang } \\
\text { berdasarkan saldo piutang air terakhir } \\
\text { dikalikan persentase yang dibuat sendiri } \\
\text { oleh PDAM. Sehingga jumlah }\end{array}$ \\
\hline
\end{tabular}




\begin{tabular}{|c|c|c|}
\hline No & $\begin{array}{c}\text { Hasil Penelitian } \\
\text { Pencatatan Transaksi Penjualan Air, Piutang } \\
\text { Rekening Air SAK - ETAP }\end{array}$ & $\begin{array}{c}\text { Pembahasan } \\
\text { Perusahaan Daerah Air Minum } \\
\text { (PDAM) Kabupaten Minahasa Utara }\end{array}$ \\
\hline & $\begin{array}{l}\text { Cara Pencatatan: } \\
\text { Dokumen : Daftar piutang selama } 3 \text { tahun buku, } \\
\text { hasil perhitungan tim tentang penyisishan piutang } \\
\text { air, laporan pemutusan sambungan baru } \\
\text { Buku Jurnal : Juranl Umum (JU) } \\
\text { Debet : Beban Peny. Kerugian Piutang Air } \\
\text { Kredit : Akum Peny Kerugian Piutang Air } \\
\text { Penyisihan : } \\
\text { Di atas } 3 \text { bulan s.d } 6 \text { bulan }=30 \% \\
\text { Di atas } 6 \text { bulan s.d } 12 \text { bulan }=50 \% \\
\text { Di atas } 1 \text { tahun s.d } 2 \text { tahun }=75 \% \text {, diajukan ke } \\
\text { Badan Pengawas untuk dihapus. } \\
\text { Di atas } 2 \text { tahun }=100 \% \text {, dan dikeluarkan dari } \\
\text { pembukuan, tetapi masih tercatat secara extra } \\
\text { comptabel. }\end{array}$ & $\begin{array}{l}\text { akumulasi penyisihan piutang usaha } \\
\text { tidak sesuai dengan perhitungan yang } \\
\text { seharusnya dilakukan PDAM dengan } \\
\text { SAK ETAP. Kendala ada pada, sebagian } \\
\text { bukti fisik piutang usaha (piutang tahun } \\
2011 \text { kebawah) yang sudah tidak ada, } \\
\text { laporan piutang yang tidak valid, dan } \\
\text { laporan umur piutang yang tidak dibuat } \\
\text { PDAM. } \\
\text { Penyisihan : } \\
<3 \text { bulan }=45 \% \\
3 \text { bulan s.d } 12 \text { bulan }=20 \% \\
>\text { Lebih dari } 1 \text { tahun }=35 \%\end{array}$ \\
\hline \multirow[t]{2}{*}{4} & $\begin{array}{l}\text { Pemulihan Penyisihan Piutang pada akhir tahun } \\
\text { Buku : }\end{array}$ & $\begin{array}{l}\text { Pemulihan Penyisihan Piutang pada } \\
\text { akhir tahun Buku : }\end{array}$ \\
\hline & $\begin{array}{l}\text { Pada setiap akhir tahun mungkin akan terjadi } \\
\text { pemulihan penyisihan Piutang Air jika hasil } \\
\text { perhitungan penyisihan piutang tahun berjalan lebih } \\
\text { rendah dari sebelumnya. } \\
\text { Cara Pencatatan: } \\
\text { Dokumen : Hasil perhitungan Tim tentang } \\
\text { Penyisihan Piutang Air, Laporan Pemutusan } \\
\text { Sambungan Langganan } \\
\text { Buku Jurnal : Jurnal Umum (JU) } \\
\text { Debet : Akum Peny. Kerugian Piutang Air } \\
\text { Kredit : Keuntungan Pemulihan Penyisihan }\end{array}$ & $\begin{array}{l}\text { PDAM tidak membuat pemulihan } \\
\text { penyisihan piutang karena perhitungan } \\
\text { beban penyisihan piutang setiap tahun } \\
\text { yang dilakukan PDAM tidak sesuai } \\
\text { SAK ETAP. }\end{array}$ \\
\hline \multirow[t]{2}{*}{5} & Penghapusan Piutang Rekening Air : & Penghapusan Piutang Rekening Air : \\
\hline & $\begin{array}{l}\text { Daftar Normatif yang telah disetujui oleh Dewan } \\
\text { Pengawas dan telah dibuatkan Surat Keputusan } \\
\text { Direksi dengan ketentuan sebagai berikut: } \\
\text { a. Piutang rekening air yang telah berumur diatas } \\
\text { dua tahun dapat diusulkan kepada Dewan Pengawas } \\
\text { untuk dihapuskan. } \\
\text { b. Berdasarkan Laporan dari Bagian Hubungan } \\
\text { Pelanggan, Sambungan Langganan telah benar- } \\
\text { benar diputus. } \\
\text { c. Piutang rekening air yang telah dihapuskan, } \\
\text { dikeluarkan dari catatan akuntansi namun tetap } \\
\text { dicatat secara extracomptabel dan tetap diusahakan } \\
\text { penagihannya. } \\
\text { Cara pencatatan: } \\
\text { Dokumen : Surat keputusan Direksi tentang } \\
\text { penghapusan Piutang Air dan Persetujuan Dewan } \\
\text { Pengawas } \\
\text { Buku Jurnal : Jurnal Umum (JU) } \\
\text { Debet: Akum Peny. Kerugian Piutang Air } \\
\text { Kredit : Piutang Rekening Air }\end{array}$ & $\begin{array}{l}\text { PDAM selama ini tidak melakukan } \\
\text { penghapusan piutang rekening air } \\
\text { dikarenakan perhitungan penyisihan } \\
\text { piutang yang tidak sesuai SAK ETAP. }\end{array}$ \\
\hline \multirow[t]{2}{*}{6} & $\begin{array}{l}\text { Penerimaan Piutang Rekening Air yang telah } \\
\text { dihapuskan : }\end{array}$ & $\begin{array}{l}\text { Penerimaan Piutang Rekening Air } \\
\text { yang telah dihapuskan : }\end{array}$ \\
\hline & $\begin{array}{l}\text { Jika terdapat pembayaran piutang Rekening Air } \\
\text { yang telah dihapuskan, maka pembayaran tersebut } \\
\text { diberlakukan sebagai pendapatan lain-lain tahun }\end{array}$ & 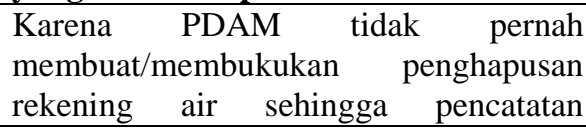 \\
\hline
\end{tabular}




\begin{tabular}{|c|c|c|}
\hline No & $\begin{array}{c}\text { Hasil Penelitian } \\
\text { Pencatatan Transaksi Penjualan Air, Piutang } \\
\text { Rekening Air SAK - ETAP }\end{array}$ & $\begin{array}{c}\text { Pembahasan } \\
\text { Perusahaan Daerah Air Minum } \\
\text { (PDAM) Kabupaten Minahasa Utara }\end{array}$ \\
\hline & $\begin{array}{l}\text { berjalan. } \\
\text { Cara Pencatatan: } \\
\text { Dokumen : Daftar Piutang rekening Air yang telah } \\
\text { dihapuskan } \\
\text { Buku Jurnal : Jurnal Penerimaan kas/Bank (JPKB) } \\
\text { Debet : Kas/Bank } \\
\text { Kredit : Pendapatan Lain-lain }\end{array}$ & $\begin{array}{l}\text { penerimaan piutang rekening air yang } \\
\text { telah dihapuskan tidak pernah dibuat } \\
\text { PDAM }\end{array}$ \\
\hline
\end{tabular}

Sumber :PDAM Kabupaten Minahasa Utara

\subsection{Pembahasan}

\subsubsection{Pengelolaan dan Pencatatan Akuntansi Piutang Pada (PDAM) Kabupaten Minahasa Utara}

Berdasarkan penelitian yang dilakukan yang dilakukan oleh peneliti pada PDAM Kabupaten Minahasa Utara mengenai analisis piutang usaha khususnya pengelolaan dan pencatatan akuntansi piutang, ditemukan bahwa banyaknya jumlah piutang tak tertagih yang disebabkan oleh perusahaan tidak menjalankan prosedur mengenai piutang sesuai dengan Standar Operasional Prosedur (SOP) yang dibuat oleh perusahaan itu sendiri dan Pencatatan SAK-ETAP khususnya dalam pencatatan penyisihan piutang. Tidak adanya laporan umur piutang tahun 20132015 sehingga perusahaan tidak membuat penyisihan piutang dan tidak mengetahui data piutang yang tertunggak dan piutang tak tertagih, banyaknya bukti laporan piutang yang tidak jelas dan perusahaan belum pernah ada penghapusan piutang khususnya yang berumur lebih dari 5 tahun. Ada juga beberapa faktor yang salah satunya adalah faktor ekonomi karena dalam proses pemasangan sambungan baru/pemasangan rekening air tidak melakukan penilaian terhadap keadaan ekonomi pelanggan melainkan hanya melakukan penilaian terhadap lokasi pemasangan sambungan air.

Hal ini berdampak pada banyaknya penunggakan piutang karena faktor ekonomi pelanggan yang taraf kehidupannya menengah kebawah. Adanya pelanggan yang sulit untuk ditagih oleh petugas penagihan akan membuat petugas semakin sulit dalam mendapatkan pembayaran piutang. Tingkat kebocoran/kehilangan air, sangat berpengaruh terhadap pendapatan penagihan karena semakin banyak tingkat kebocoran air maka semakin sedikit piutang yang akan ditagih kepada pelanggan. Banyaknya meteran air pelanggan yang rusak juga dapat mempengaruhi keadaan piutang karena apabila terlalu banyak meteran air pelanggan yang rusak, piutang yang seharusnya bertambah malah berkurang.

Kapasitas produksi air yang tidak maksimal juga merupakan salah satu penentu banyaknya piutang yang harus ditagih kepada pelanggan karena apabila produksi air tidak maksimal akan mengakibatkan jumlah penggunaan air oleh pelanggan semakin kecil, sehingga dapat mempengaruhi jumlah piutang yang berakibat pada pendapatan perusahaan. Oleh karena itu sangat diperlukan pelayanan yang maksimal terhadap masyarakat dengan membuat penambahan penampungan air agar pendistribusian air bisa maksimal sehingga dapat meningkatkan jumlah penggunaan air oleh pelanggan. Hal ini juga diakui oleh perusahaan sebagai beberapa faktor penyebab banyaknya penunggakan piutang. 


\subsubsection{Analisis Rasio Piutang Usaha Pada PDAM Kabupaten Minahasa Utara}

Tabel 2

Hasil Perhitungan RTO dan ACP di PDAM Kabupaten Minahasa Utara Periode 2013-2015

\begin{tabular}{|c|c|c|}
\hline Tahun & RTO & ACP \\
\hline 2013 & $2,3 \mathrm{Kali}$ & 156 Hari \\
\hline 2014 & $1,1 \mathrm{Kali}$ & 327 Hari \\
\hline 2015 & $0,8 \mathrm{Kali}$ & $450 \mathrm{Hari}$ \\
\hline
\end{tabular}

Sumber :PDAM Kabupaten Minahasa Utara (data olahan)

Dari hasil perhitungan Receivable Turn Over (RTO) di atas, kita dapat mengetahui bagaimana keadaan tingkat perputaran piutang dagang yaitu dari piutang menjadi kas pada Perusahan Daerah Air Minum (PDAM) Kabupaten Minahasa Utara. Dari rasio perhitungan RTO dapat kita lihat bahwa tingkat perputaran piutang perusahaan dari tahun 2013 sebanyak 2,3 kali, tahun 2014 sebanyak 1,1 kali, tahun 2015 0,8 kali, mengalami fluktuasi sehingga harapan perusahaan piutang terjadi setiap bulan dalam 1 tahun sebanyak 12 kali. Hal ini berarti bahwa tingkat perputaran piutang di PDAM Kabupaten Minahasa Utara dalam periode 1 tahun sangat lambat dari target yang diharapkan 12 kali.

Dengan melihat periode pengumpulan piutang atau Average Collection Period (ACP) kita bisa melihat dalam jangka waktu berapa hari piutang akan berubah menjadi kas. Berdasarkan data Perhitungan Average Collection Period (ACP) di atas, hasilnya tergantung pada hasil perhitungan Receivable Turn Over (RTO), semakin besar Receivable Turn Over (RTO) semakin baik bagi perusahaan, karena modal yang terikat dalam piutang dapat kembali dengan cepat menjadi kas. Periode rata-rata pengumpulan piutang lebih besar dari pada batas waktu pembayaran yang telah ditetapkan perusahaan, berarti bahwa cara pengumpulan piutang kurang efisien dan berarti banyak para pelanggan yang tidak memenuhi syarat pembayaran yang telah ditetapkan oleh perusahaan yaitu harapan perusahaan terhadap pengembalian piutang menjadi kas adalah 30 hari sesuai dengan ketentuan pelunasan piutang paling lambat 30 hari setelah invoice diterima oleh pelanggan.

Rasio tunggakan dan rasio penagihan tidak dapat dihitung karena data piutang dalam neraca dan data piutang dari bagian piutang angkanya berbeda dan Perusahaan Daerah Air Minum (PDAM) Kabupaten Minahasa tidak membuat cadangan piutang, sehingga kedua rasio ini tidak dapat dianalisis.

\section{KESIMPULAN DAN SARAN}

\subsection{Kesimpulan}

Berdasarkan hasil pembahasan yang diuraikan dalam penelitian diatas maka dapat disimpulkan sebagai berikut :

1. Hasil analisis dan penelusuran terhadap Perusahaan Daerah Air Minum (PDAM) Kabupaten Minahasa Utara mengenai pengelolaan piutang yang dilihat dari pencatatan pendaftaran prosedur sambungan baru telah sesuai dengan Pencatatan Standar Akuntansi Keuangan.

2. Hasil analisis table 4.6 cheklist sesuai atau tidak sesuai Prosedur Akuntansi yang dijalankan PDAM Kabupaten Minahasa Utara dengan Pencatatan Penjualan Air, Piutang Air SAK ETAP tentang Pencatatan akuntansi piutang berdasarkan SAK ETAP (2009) dan Standar Operasional Prosedur (SOP) PDAM Peraturan Menteri dalam negeri nomor 2 tahun 2007 diperoleh kesimpulan bahwa, dalam pengelolaan piutang dan pencatatan akuntansi piutang PDAM Kabupaten Minahasa Utara masih 
banyak ketidaksesuaian dengan SAK ETAP (2009) dan Pedoman Akuntansi PDAM Peraturan Menteri dalam negeri nomor 2 tahun 2007.

3. Tingkat perputaran piutang/Receivable Turn Over (RTO) PDAM Kabupaten Minahasa Utara setiap tahun mengalami perputaran yang sangat lambat dan tidak mencapai target yang diharapkan perusahaan yaitu sebanyak 12 kali dalamsatu tahun, hasil perhitunganPeriode Pengumpulan Piutang/Average Collection Period (ACP) PDAM Kabupaten Minahasa Utara menunjukkanbahwa bagian penagihan bisa mengumpulkan piutang sampai menjadi kas dalam waktu 450 hari yang artinya tidak mencapai target ketentuan syarat pembayaran perusahaan PDAM selama 30 hari, sedangkanrasio tunggakan dan rasio penagihan tidak dapat dihitung karena data piutang dalam neraca dan data piutang dari bagian piutang angkanya berbeda dan Perusahaan Daerah Air Minum (PDAM) Kabupaten Minahasa tidak membuat cadangan piutang, sehingga kedua rasio ini tidak dapat dianalisis.

\subsection{Saran}

Berdasarkan penelitian yang telah dilakukan, berikut ini adalah saran atau rekomendasi yang diberikan oleh peneliti :

1. Bagi Perusahaan Daerah Air Minum (PDAM) Kabupaten Minahasa Utara.

a. Perusahaan Daerah Air Minum (PDAM) Kabupaten Minahasa Utara agar menyelesaikan laporan umur piutang mulai dari tahun 2013, 2014, 2015, sampai bulan berjalan.

b. Perusahaan Daerah Air Minum (PDAM) Kabupaten Minahasa Utara dalam hal ini bagian piutang melakukan sinkronisasi data piutang dengan bagian pembukuan.

c. Dalam pengelolaan dan pencatatan akuntansi piutang Perusahaan Daerah Air Minum (PDAM) Kabupaten Minahasa Utara sebaiknya berpedoman serta disesuaikan dengan SAK ETAP dan Standar Operasional Prosedur PDAM Peraturan Menteri dalam negeri nomor 2 tahun 2007.

d. Meningkatkan efisiensi penagihan dan meningkatkan peraturan pembayaran supaya tidak terjadi lagi piutang macet.

e. PDAM Kabupaten Minahasa Utara meningkatkan pelayanan kepada pelanggan dalam hal distribusi air karena salah satu penyebab adanya piutang usaha yang tidak tertagih karena pelayanan yang diberikan PDAM, dalam hal ini distribusi air tidak optimal.

f. PDAM Kabupaten Minahasa Utara menghapuskan piutang usaha yang berumur lebih dari 5 tahun atau piutang usaha yang tidak memiliki bukti yang jelas. (Bukti piutang hilang)

2. Bagi Perguruan Tinggi sebaiknya dapat ikut melakukan sosialisasi, penyuluhan dan pelatihan mengenai penerapan SAK ETAP dalam Keputusan Menteri Negeri Otonomi Daerah Nomor 8 Tahun 2000.

3. Bagi penelitian selanjutnya diharapkan dapat meneliti dengan periode penelitian yang lebih panjang atau dengan sampel penelitian yang lebih banyak.

\section{DAFTAR PUSTAKA}

Banteng, Djayanti, Astri, 2013. Analisis Pengakuan Piutang Tak Tertagih dan Penyajian Laporan Keuangan pada PT. Bank Sulut. Skripsi, Fakultas Ekonomi UNSRAT. Manado.

Hery., 2013a. Akuntansi Dasar 1 dan 2. PT. Gramedia Widia sarana Indonesia. Jakarta. 
J.,Jerry., Weygandt, Paul D., Kimmel. \& Donald E,Kieso., 2013. Financial Accounting. IFRS Edition. Hoboken, New Jersey: John Wiley \& Sons.

Karya, Cipta, 2015. Modul Laporan Keuangan PDAM Berdasarkan SAK

ETAP. Kementerian Pekerjaan Umum dan Perumahan Rakyat, Direktorat Pengembangan Sistem Penyediaan Air Minum. Jakarta.

Kasmir., 2012. Analisis Laporan Keuangan. Edisi 3, Rajawali Pers, Jakarta.

Nurjannah, 2012. Analisis Tingkat Perputaran Piutang Pada PT Adira Finance

Makassar. Skripsi. Jurusan Akuntansi Fakultas Ekonomi dan Bisnis Universitas Hasanuddin.Makassar.http://repository.unhas.ac.id/bitstream/handle/123456789/1743/S KRIPSI\%20NURJANNAH.pdf? sequence=2. Diakses : Januari, 28, 2017.

Syakur, Syafi'I, Ahmad., 2015. Intermendite Accounting. AV Publisher, Jakarta.

Sugiyono., 2013. Metode Penelitian Kuantitatif, Kualitatif dan $R \& D$. Alfabeta, CV. Bandung.

Tanor, Melissa, 2015. Analsis Laporan Graha Internasional Keuangan dalam Mengukur Kinerja Keuangan pada PT. Bank Artha Tbk. Jurnal EMBA. Vol. 3 No. 3. Manado. http://ejournal.unsrat.ac.id/index.php/emba/article/view/9535

Sadeli, Lili., 2015. Dasar-dasar Akuntansi. Edisi 1. Cetakan 9. Bumi Aksara. Jakarta.

Sutrisno., 2008. Manajemen Keuangan : Teori, dan Konsep dan Aplikas, Edisi Pertama. Penerbit : Ekonisia. Yongyakarta.

Wowor, Sheren, 2017. Evaluasi Penerapan Akuntansi Pajak Air Permukaan Pada Perusahaan Daerah Air Minum Kabupaten Minahasa Utara. Jurnal EMBA. Vol 12 No. 01. Manado. http://ejournal.unsrat.ac.id/index.php/emba/article/view/4417 